\title{
Muslim Migration to East Nusa Tenggara: Their Implications for Faith Communities
}

\author{
Michael R. Quinlan', Bernard Adeney-Risakotta ${ }^{2}$, Zainal Abidin Bagir ${ }^{3}$ \\ Inter-Religious Studies, The Graduate School, Universitas Gadjah Mada \\ \{quinlan.michael@mail.ugm.ac.id¹, baryogya@gmail.com², zainalbagir@ugm.ac.id³
}

\begin{abstract}
Migration within Indonesia continues to shape and reshape countless cities and islands across the archipelago. Rural to urban migration transforms metropolitan centers, increasing economic productivity while straining infrastructure. Transmigration carries new peoples and technologies to developing lands, inviting competition for resources at the risk of conflict. Migration and the demographic shifts that result bring benefits as well as pose challenges to both migrants and their host communities. Based on ethnographic research of 108 Muslim migrants to East Nusa Tenggara (NTT), this paper offers a reflection on the phenomenon of Muslim migration to Christian-majority areas and the implications for faith communities. The study was conducted between February 2018 and February 2019. Drawing from the experiences of migrants on the islands of Sumba and Timor, this paper will discuss the effects of migration on religious belief, the potential for conflict due to religious illiteracy, and the role faith groups can play to minimize intercultural and interreligious tension.
\end{abstract}

Keywords: migration and religion, Muslim-Christian relations, Indonesia

\section{Introduction}

During the writing of this paper, violence erupted in Indonesia once again. Papuan students attending university in Surabaya, East Java, allegedly desecrated an Indonesian flag in advance of August 17th Independence Day celebrations. A video of these claims went viral and several organizations joined together in protest [1]. The protest evolved into a riot, and the mob stormed the students' dormitory chanting racial slurs. Counter protests broke out in the regions of Papua and West Papua. These protests quickly escalated into violent rioting resulting in the destruction of government property and local businesses. The violence hit its peak more than a month later, on September 23, 2019 when 33 people died in a single day [2]. Twenty-five of those killed were migrants.

In Papua, locals and migrants provide a very clear visualization of the racial and political tensions. The migrants, mostly Austronesian Indonesians, stand in contrast to the ethnic features of local Papuans. As seen in the death toll above, the violence has turned anti-migrant. Though primarily racially and politically motivated, the conflict has the potential to become interreligious. Most of the migrants, after all, are Muslim, while most of the local Papuans identify as Christian. Indeed, some Islamic hardline groups have reportedly called for jihad in Papua in response to the killings of migrants. This led to suspicions that a visiting group from 
Jamaah Tabligh had arrived in Papua to engage in violent jihad when their intentions were merely to commit dakwah among the Muslim community [3].

The context for this study is not too dissimilar from that of Papua. The people of NTT carry stigmas of being "poor, isolated, [and] backward" when compared to the rest of Indonesia [4]. Both regions struggle with underdevelopment. Christianity remains the majority faith in both areas. And, migrants to each context are predominantly Muslim. Papua, which is at the threshold of becoming a migrant majority, may offer a vision of the future and the inevitable results of migration.

With the role migration plays in shifting demographics and its historical relation to conflict within Indonesia, this research seeks to advance our knowledge of the migrant experience. This study examined the experiences of Muslim migrants to Christian-majority East Nusa Tenggara (NTT) in order to discern migration's effect on the religion of migrants. Our ethnographic inquiry followed a five-pillared framework to explore migrants' motivations, adaptation, and perspectives of the Christian majority as well as how migration influenced religion, both individually and corporately. Below, we offer a summary of the study's findings and the implications for faith communities.

\section{Summary of Findings}

\subsection{Methodology}

This paper follows a larger dissertation project which sought to develop an ethnography of Muslim migrants to Christian-majority NTT. The pillars of the ethnographic framework constructed for the research were: (1) motivations for migration, (2) adaptation to environment, (3) effect on religious belief and/or practice, (4) migrant religious institutions, and (5) migrant perceptions of the Christian majority. Data collection involved semi-structured interviews of 108 Muslim migrants to NTT. Research was conducted in five locations, two on Sumba Island and three on Timor Island. The Sumbanese locations were Waikabubak, West Sumba, and Anakalang, Central Sumba. The Timorese locations included Kupang City, Baun Village, Kupang Regency, and Oe'Ekam, South Central Timor. The study limited participants to migrants from Muslim-majority sending societies within Indonesia. Fifty participants originated from Java, 36 from Bima, 16 from South Sulawesi, and the remaining six from other islands. A summary of the findings is presented below following the ethnographic framework.

\subsection{Motivation}

The research aimed to understand the decision-making process of migrants and whether common suspicions of migration as Islamization had any merit [5], [6], [7]. Economic concerns were the driving force behind participants' migrations. Eighty-six percent of migrants moved in search of work, as part of a job posting, or to accompany family who had migrated for work. These noted strong competition, difficulty in finding employment, and high levels of corruption as reason for leaving their home islands. Only one migrant surveyed moved to the region for the purposes of proselytization. "Called to bring the faith to Dili," he arrived in East Timor in 1998, evacuating to NTT the same year and continuing his ministry in Kupang and Atambua [MLN, personal interview, January 2019]. 


\subsection{Adaptation}

Although Muslim migrants moved from one region to another within Indonesia, their migrations required linguistic, cultural, and religious adaptations. Migrant networks aided the adaptations of later migrants and therein the perpetuation of further migration [8]. Earlier migrants, therefore, experienced more difficult transitions due to a lack of both infrastructure and an established Muslim community. Entering a non-Muslim context, migrants were struck by the lack of or distance to mosques in addition to the prevalence of dogs and pigs, in the market and roaming free. The shock of adaption resulted in a disruption of faith practices as migrants reoriented themselves to the context. Unable to hear the adzhan, migrants adjusted to praying by the hour or through the use of mobile applications. The most effective adaptation strategy of migrants was helping to advance religious literacy regarding Islam among their neighbors and coworkers.

\subsection{Effect on Religious Belief and Practice}

The activities involved in migration (finding work, food, and shelter) coupled with a nonMuslim majority environment cause disruptions in migrants' religious practice. The absence of legitimating structures for migrants' faith results in their religion shifting from a communal expression to a personal one, similar to Luckmann's theory of the individualization of religion [9]. That is, from an institutional perspective, migrants' faith may appear lacking, but, in reality, they have maintained their religious belief. Migrants relate that the onus for their faith is on them and they feel greater ownership of their beliefs (i.e. they are Muslim because they choose to be, not because they were born Muslim). Seventy percent of migrants report that their faith increased due to the changes brought about by their migration. The processes of individualization as well as a stronger sense of personal religious liberty has allowed for these increases. The lack of social pressures from a Muslim majority community provides migrants freedoms not only to choose their own stream (aliran) of Islam, but to follow other religious paths. Five of the migrants surveyed converted to Christianity after their migration, three of these having married Timorese Christian men.

\subsection{Migrant Religious Institutions}

Additional data is needed to discern changes to migrants' perceptions of Christians pre- and post-migration. From the responses, we can glean that those within the Muslim-majority sending societies held negative views of Christians or none at all due to the extremely low Christian populations in the regions. Migrants overwhelmingly had positive experiences with Christians in their new locations, believing themselves to be welcomed, accepted, and respected by the Christian majority. Migrants related increased knowledge of Christian practices aiding in their interaction with the Christian culture. Migrants did not consider themselves targets for Christianization or victims of discrimination. Ninety percent of migrants found NTT more tolerant than their sending societies. 


\section{Results And Discussion}

Migration's connection to interreligious conflict within Indonesia inspired this study in hopes that increased knowledge of the migrant experience would provide insights into potential sources of conflict and conflict prevention. Below, we will discuss the Muslim migrant experience further and opportunities for receiving communities to assist both migrants and locals. At the heart of the tensions in NTT is a lack of religious literacy. Muslim migrants' most effective strategy in preventing conflict with their Christian neighbors has been advancing their communities' knowledge of Islam. Mutual dialogue between migrants and locals about their religious traditions helps to minimize misunderstandings. In effect, this study is an exercise to that end.

Following the outline of our study, the first concern we need to address is motivation. The suspicion that migration is a means of Islamization cannot be sustained. Conversions do occur, but these are largely due to intermarriage. Rarer, spontaneous conversions include migrants converting to Christianity as well as locals converting to Islam. Christians need to be aware that migrants come seeking economic prosperity and have little desire to spread their faith. Further, although proselytization is restricted in Indonesia [Regulation No. 70/1978], both Christians and Muslims are complicit in its practice across NTT. Muslims and Christians need to openly address this issue and come to a mutual decision that 1) proselytization should be allowed as a free expression of one's faith or 2) proselytization is a legally censured act and should, therefore, be forbidden. The latter is the only politically expedient option.

The early stages of the resettlement process prove most difficult for migrants as they adapt to their new surroundings. The development of migrant networks wherein migrants benefit from the knowledge and successes of earlier migrants mitigates some of the complications in transitioning to life in NTT. However, there remain many opportunities to aid migrants in this process. Migrants surveyed revealed that they received no support for their relocation and resettlement, educational or otherwise, from their mosques. Some migrants noted that the relationships they made at the mosque with other migrants upon arrival to NTT benefitted their adaptation as migrants shared information on job openings and available housing. The mosque provides a centralized location for migrants to interact, and the lack of guidance and support for migrants is a missed opportunity for these congregations. In addition to providing theological and spiritual direction to migrants pertaining to interreligious coexistence, mosques could offer training and practical advice regarding local culture and customs.

Migration requires acculturation on the part of migrants while simultaneously necessitating accommodation by the local community. The responsibility to maintain peace and interreligious harmony does not lie solely on the migrant community. The local population must play an active role in the pursuit and maintenance of tolerance. Migrants do not enter an abstract Christian reality, they enter the homes, workplaces, and schools of Christians. The reception of migrants is best done when both locals and migrants are culturally and religiously informed. Churches, Christian-owned/operated businesses and workplaces, and local schools need to develop programs which help the local population understand the religious regulations of Muslims in order to create a more inclusive atmosphere. The researcher would argue that this would be best accomplished through active participation of and cooperation with Muslim residents and congregational leaders.

The most immediate concerns of migrants on arrival is the need to find halal food. Migrants have responded to this need by entering the marketplace, opening restaurants, or operating food stalls which cater to Muslims. The Christian majority is often unaware of or misinformed on these issues. Ignorance of Muslim dietary needs carries the potential for offense. In rural Sumba, 
migrants shared about how the local community invited them to a wedding celebration. The hosts offered alcohol and pork to their Muslim neighbors which they refused on account of their religion's prohibitions. The hosts became offended at the rejection of their hospitality. The migrants, in turn, were upset because there were no provisions for them. Stories such as these were common in rural areas where there are smaller Muslim populations. These problems did not just occur in private homes in rural villages. Urban office staff catered in non-halal food for employee meetings. Public school cafeterias served pork and dog at lunch. The lack of awareness of halal-haram concerns included members of one regency's Religious Harmony Forum (Forum Kerukunan Umat Beragama, FKUB). At a meeting with the migrant community, the Christian leader of the FKUB said, "Why is it so hard for Muslims to eat?" This prompted the head of the local chapter of Majelis Ulama Indonesia (MUI) to meet with FKUB representatives to explain Muslim dietary law. Religious illiteracy within the very institution charged with protecting religious harmony reveals the need for interreligious education at all levels of society.

Migrants have fewer places to pray than in their sending societies. Rural villagers may have access to only one mosque and, if they work in a more remote region, they may be precluded from worshipping at the mosque due to time constraints. Migrants have adapted to this by praying in their homes, but a continuing problem is access to worship space during office hours. With the exception of government office buildings, there are no mushollah in private offices or public schools. Employers allow migrants to utilize a closet, empty room, or their classrooms for prayer. Unfortunately, these places are often dirty and therefore do not provide a pleasant atmosphere for prostration. In addition to this, employers routinely schedule meetings during prayer times, including mandatory Friday prayers. Providing clean worship spaces and an adequate allowance of time will assist migrants in maintaining their prayer habits.

The individualization of migrants' beliefs influences Islamic institutions. The focal point of faith shifts from mosque to home. This holds the possibility for isolation as the congregation within the migrant context no longer serves as a central point for socialization. Migrants reported that it was common for people to pray at the mosque and immediately go home, whereas in their sending societies there was vibrant fellowship. In Kupang, interfaith organizations, like Kontak Kerukunan Sosial (K2S) fill this gap. K2S provides a forum for socialization and community service for Javanese migrants of any faith. K2S began with the mission to connect Javanese migrants and provide for shared needs and now represents over 3,000 migrant families. Komunitas Peacemaker Kupang (KOMPAK) is another important social group serving Kupang and the surrounding area. This group consists of young people from multiple faiths and includes both migrants and locals who come together to promote religious tolerance. They train other youth and young adults in schools and universities to become advocates for peace. K2S and KOMPAK offer helpful models for other regions, providing platforms for socialization, service, and the advancement of interreligious harmony.

Changes within the Muslim community across Indonesia, namely a growing conservatism and the proliferation of radical groups, affects the interreligious environment of NTT. Early migrants to NTT argued that more recent migrants carry the problems associated with political Islam and identity politics to NTT. While this may be true, identity politics play a large role in the Christian community as well. Both groups must be careful in this regard. On Sumba, the Muslim community actively limits the Muslim groups they allow to operate. Several years ago, a group of 20 members of Jamaah Tabligh moved to the island for the purposes of proselytization. To preserve harmony, the wider Muslim community expelled the group from Sumba. In Kupang, the Muslim community has been less effective in this regard as Islamist groups such as the Islamic Defenders' Front (Front Pembela Islam, FPI) and Hizbut Tahrir 
Indonesia (HTI) have considerable support in the area. A measure of self-policing by religious groups, in terms of preventing radicalism and groups which pose threats to unity, is needed to preserve peace in NTT.

Islamic education centers exist in three of the five research areas. There are no observable trends in migrants' school choice as migrants may send one child to madrasah and another to public school and, as a whole, migrants remain largely divided in their preference. Islamic education provides the benefits of more intensive religious instruction while limiting interactions with non-Muslims. Naturally, students attending Islamic schools had fewer Christian friends than their public school counterparts. This self-segregation in schooling (in addition to religious and ethnic enclaving) may prove harmful to interreligious tolerance in the future. Public schools present issues for migrants as well. Besides the issues of halal food and a lack of worship space, there is a shortage of religious education teachers in NTT (as there is nationwide). As there are no Islamic education teachers in the school, some migrant children from Anakalang attend the mandatory Christian education class. In Muslim-majority areas, the reverse may occur, Christian students attending classes for Muslim students. Here, national regulations require a specialized teacher for this position. There is no easy solution for this except to lobby the government to make changes (e.g. allowing Muslim teachers with accreditation in other subjects to teach religion classes as an emergency measure). Showing solidarity with a disaffected minority may benefit religious minorities across the nation as well as strengthen bonds between religious communities locally.

On Timor in 1998, anti-Muslim rioting in Kupang displaced thousands of Muslim migrants. Christian communities providing protection and refuge to Muslims fleeing the violence fostered a sense of communal solidarity which remains until today. Migrants understand the events of 1998 to be an aberration, noting the high tolerance experienced in everyday life. However, more recently, two events reveal the potential for further conflict. In 2010 and 2011, small acts of communal violence halted the construction of mosques in Langgaliru, Central Sumba, and Batuplat, Kupang. Reciprocal acts of intolerance play a role in both events in Kupang. Actions against Christian minorities outside the region can affect Muslim minorities within NTT. Standing in contrast to these events are the weekly expressions of tolerance seen in the protection of worship spaces in Waikabubak and the mutual protection during holiday celebrations. Communities in NTT and across Indonesia need to foster habits of reciprocal acts of kindness as opposed to the more common reciprocal acts of violence.

\section{Conclusion}

Migration brings the challenges of diversity and competition for resources. In Papua, these challenges have resulted in the sporadic and recent outbreaks of violence. Knowing more about the migrant experience provides us with insights into the precursors of conflict. Muslim migration to NTT poses challenges to both migrants and the host community. Migrants face difficult adaptations to a language, culture, and religious atmosphere not their own. Faith communities can mediate the burden of resettlement for migrants and their communities as they develop programs for Muslims and Christians, migrants and locals, to share knowledge of culture and religion with one another. Advancing religious and cultural literacy assists migrants in adapting to the context and their neighbors to better accommodate their needs. Fostering relationships of trust and demonstrations of solidarity will help build a foundation of tolerance in the hopes of preventing future conflict. This study presents the migrants' experience and 
therein is only half of the equation. The experience and perspectives of the receiving society demand further study.

\section{References}

[1] Nathalia, T.: Alleged instigator apologizes for racist actions against Papuan students in Surabaya. 2019 Aug 20 [cited 2019 Oct 30]. Available from: https:/jakartaglobe.id/context/allegedinstigator-apologizes-for-racist-actions-against-papuan-students-in-surabaya/.

[2] Davies, E.: Indonesia says over 11,500 have fled violence-hit Papuan town. 2019 Oct 3 [cited 2019 Oct 30]. Available from: https://www.reuters.com/article/us-indonesia-papua/indonesia-saysover-11500-have-fled-violence-hit-papuan-town-idUSKBN1WI1E8.

[3] Felisiani, T.: Kapolda Papua pastikan keberadaan Jemaah Tabligh di Jayapura bukan kelompok jihad. 2019 Oct 7 [cited 2019 Oct 30]. Available from: https://www.tribunnews.com/nasional/2019/10/07/kapolda-papua-pastikan-keberadaan-jemaahtabligh-di-jayapura-bukan-kelompok-jihad.

[4] Corner, L.: East and West Nusa Tenggara: isolation and poverty. In: H. Hill editor. Unity and diversity, regional economic development in Indonesia since 1970. New York: Oxford University; 1989. p. 180-206 (197).

[5] Bertrand, J: Nationalism and ethnic conflict in Indonesia. Cambridge: Cambridge Univ. Press; 2009.

[6] Farhadian, C.E.: Christianity, Islam, and nationalism in Indonesia. New York: Routledge; 2005.

[7] Wanggai, T.V.M.: Rekonstruksi sejarah umat Islam di tanah Papua. Jakarta: Badan Litbang dan Diklat, Departemen Agama RI; 2009.

[8] Masey, D.S., España, F.G.: The social process of international migration. Science. 1987 237(4816), 733-738 (736). Available from: http://www.jstor.org/stable/1699201.

[9] Luckmann, T.: The invisible religion: the problem of modern society. New York: Macmillan; 1967. 